\title{
Modelling COVID-19 Data for Economic Balance Towards Sustainable Consumer and Business Support
}

\author{
Silvia-Elena Cristache ${ }^{1}$, Daniela Serban ${ }^{2}$, Adina Ţiței ${ }^{3}$ and Codrin Nisioiu ${ }^{4}$ \\ ${ }^{1) 224)}$ The Bucharest University of Economic Studies, Bucharest, Romania. \\ 3) "Ovidius" University of Constanta, Constanta, Romania. \\ E-mail: danielaserban2002@yahoo.com; E-mail: csilvia2005@yahoo.com \\ E-mail: adinatitei@yahoo.com; E-mail: nisioiucodrin@gmail.com
}

\begin{abstract}
Please cite this paper as:
Cristache, S.E., Serban, D., Titei, A. and Nisioiu, C., 2021. Modelling

COVID-19 Data for Economic Balance Towards Sustainable Consumer and

Business Support. In: R. Pamfilie, V. Dinu, L. Tăchiciu, D. Pleșea, C.

Vasiliu eds. 2021. 7th BASIQ International Conference on New Trends in

Sustainable Business and Consumption. Foggia, Italy, 3-5 June 2021.

Bucharest: ASE, pp. 711-719 DOI: 10.24818/BASIQ/2021/07/091
\end{abstract}

\begin{abstract}
Although a series of restricitve measures have been implemented in Romania to fight the COVID-19 pandemics, the progress registered on the economic, social and sanitary level was relatively low in 2020 and in 2021. The objective of the study was to model the Romanian COVID-19 health crisis indicators in order to identify ways to support the economic equilibrium necessary for sustainable development of businesses and supporting the consumers. Using data collected from the WHO 2020 and 2021 database about Romania, a valid linear multiple regression model was obtained, in order to identify the influence factors over the total number of COVID - 19 cases. It was highlighted that a one-unit increase in mild forms of the virus will generate an increase of 5 cases in total disease, resulting in negative effects on the economy, labor market and eventually the final consumer. The originality of this study consists in the application of statistical and econometrical research methods and techinques to time series, which describe macroeconomic variables pertaining to the COVID-19 pandeminc. This study highlights a number of implications of the COVID-19 pandemic: the inability of the Romanian public health system to cope with the sanitary crisis; major social and economic disequilibria (with respect to the growing unemployment rate and the decline in the people's standard of living). Another major implication cited in the current study is the consumers' inclination towards local products and services.
\end{abstract}

Keywords: COVID_19 pandemic, macroeconomic indicators characterizing the health crisis, multiple regression model, parameter estimation, economic equilibrium, labor market, consumer.

DOI: 10.24818/BASIQ/2021/07/091

\section{Introduction}

The pandemics generated by SARS COV2 inducing the COVID-19 disease, started in Hubei province in China (Die WELT, 2020). The exponential increase in cases as well as the global expansion has led to major problems in terms of long-term infection management world-wide. In this context, on March 11, 2020, the WHO declared the COVID-19 disease a pandemic. The objective of this study is to analyze the impact of the major indicators characterizing the Romanian pandemics on the number of total cases of disease due to this virus and to further characterize the influence of the pandemics upon the economic and social balances. The result of this study should answer the question: Will the improvement of the health status of the Romanian population and the decrease in the number of COVID-19 cases lead to the improvement of the economic and social aspects existing at this moment, not only at global level, but also in Romania? The economic situation depends on the level of development of each European country, the degree and stage of the pandemics and the access 
to resources offered by EU and other international bodies. The COVID-19 pandemic has also had a social impact on social security systems, putting healthcare, unemployment insurance and pensions under pressure because the effects of the pandemic and increasing financial pressure. Within this context, the latest Ernst/Young Romania study from March - June 2020, considers the characterizing the patterns in consumer behavior in Romania, as well as possible predictions regarding the evolution of consumption in Romania. These scenarios and predictions stated by EY study is based on the latest changes in the socio-economic patterns, as well as in the preferences of the Romanian consumers, related to this completely new pandemic context. The study also states that a major trend among Romanian consumers was the reduction of budgets for non-essential expenditures, quality becoming the main purchasing factor followed by the price. Also, the EY study highlighted the fact that the volume of purchases increased, observing a migration to local products compared to the imported ones.

Considering the restrictions imposed regarding the social distance, implemented by the Romanian Government for the decrease of the transmission rate of the virus, the food and non-food products were ordered mainly online using the home delivery services This consumer behavior to buy mainly from the online environment in conditions of health insecurity is also a consistent consequence (Pelau, at al., 2020) of the growing world population and unbalanced access to resources, the concept of food waste having an essential role in last years, even before the pandemics. Food waste has a negative impact on the economy, society and the environment. There has been a growing demand for organic and sustainable foods as COVID-19 raises awareness of the relationship between nutrition and health. Romanian Academy paper, "Assessments of the macroeconomic impact of COVID-19" from 2020, the crisis has affected and will continue to strongly affect certain segments of market services (tourism, hotels, restaurants, cultural services) and, through a chain effect, the industry, constructions and public services. The crisis caused by the COVID-19 pandemic severely affected the extremely fragile balance of the Romanian labor market (Albu, at al, 2020). This severe imbalance was the result of the action of divergent influences, at the confluence between the determinants of labor demand and supply. In conclusion, the COVID-19 pandemic that marked the past 13 months, led to a sudden and deep recession around the world putting pressure on the health and social protection systems, businesses and working relations. In this context, the analysis of the measures communicated to characterize the health crisis, represented in our study an important element for maintaining the economic and social balance necessary for sustainable business development and the support of the consumer.

\section{A brief literature review}

At the time of the declaration of the COVID-19 pandemic by the WHO in 2020 in the Raport 51, very little data and analysis about this virus and its effects in the population were known, namely: very high degree of contagiousness due to the acrogenic transmission of the virus; very high level of assessment due to the spread and severity of the damage; all age groups are affected; at that time, the data suggested that two age groups were considered to be at high risk with severe evolution of the infection: the elderly and people with comorbidities; the risk of severe infection increases in people over 40 years.

\section{Health crisis}

The 2020 PricewaterCoopers survey on post-COVID-19 consumer behavior, the 2020 Global Consumer Insights Survey, showed that the online shopping increased exponentially and intentions on expenditure are deeply affected by the pandemics. Consumer behavior changed in 2020, following the outbreak of the COVID-19 pandemic, highlighting three major trends: digital adaptation, concern for health and sustainability. A large part, $45 \%$ of consumers globally say that healthcare is one of the top three reasons to live in a city; $69 \%$ are more are concerned with mental health and well-being, and $43 \%$ expect businesses to be responsible for their impact on the environment. At the same time, the PwC study (2020) showed that consumers' interest in health, well-being, and diet has an increasing trend and will influence on the one hand the industries that offer products and services in these categories, and on the other hand, the general consumption habits. 
Regarding the evolution of the number of cumulative cases COVID-19, for the period of analysis March 2020 -March 2021 (Coronavirus COVID-19 România Project, statistical analysis), in Romania it can be observed that the number of cumulated cases registered successive increases with a maximum point in January 2021. The new cases had a cyclical evolution during the period of analysis with a significant decrease in July and September 2020 (Figure no.1). Number of deaths and confirmed cases of COVID - 19 registered a steady upward trend between March 2020 and March 2021, with all restrictions imposed and the start of vaccination in our country in December 2020.

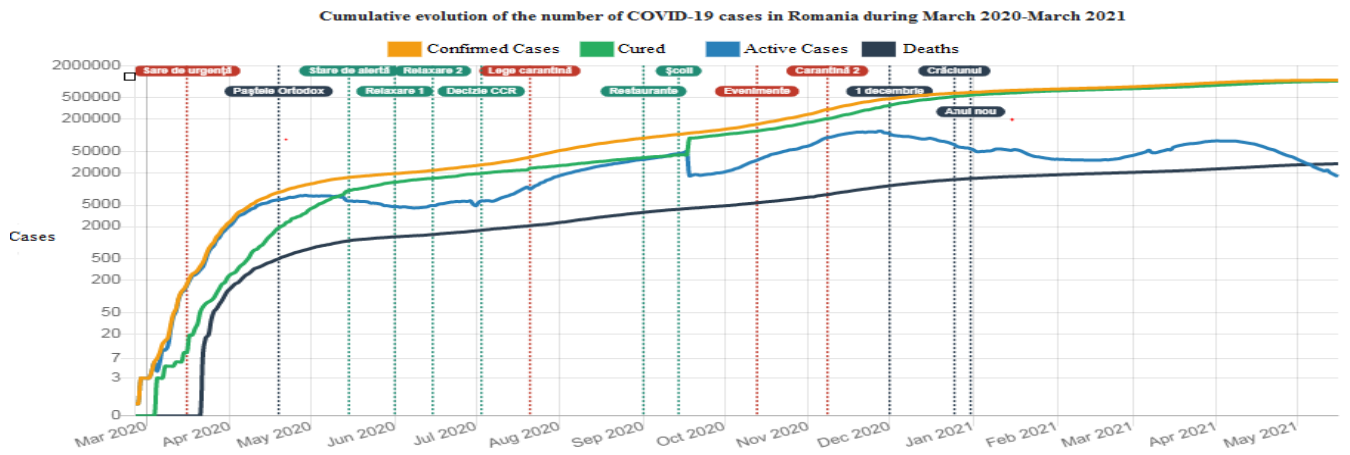

Figure no. 1. Cumulative evolution of the number of COVID-19 cases in Romania during March 2020-March 2021

Source: https://covid19.geo-spatial.org/statistici/statistici-generale?chart=ziua-fata-de-cazuri-cumulative

Regarding the number of daily deaths depending on gender, as a result of the COVID-19 pandemic (Coronavirus COVID-19 Romania Project), in Romania, during the period March 2020-March 2021, the highest values were registered in the period November 2020-January 2021 both in women as well as men. It should be noted that males were more affected by the pandemic during the analyzed period. (Figure no. 2) Regarding the analysis of the total number of COVID-19 cases in Romania by age groups, it is observed that until March 31, 2020 the age groups between 40-49 years and 50-59 years (51970 cases and 47084 cases) were the most affected in relation to the age group 0-9 years where the fewest cases were registered (5096). The total number of cases in Romania on March 22, 2021 by age groups keeps the same distribution, the most affected age groups being those between 40-49 years and 50-59 years (182436 cases and 165925 cases).

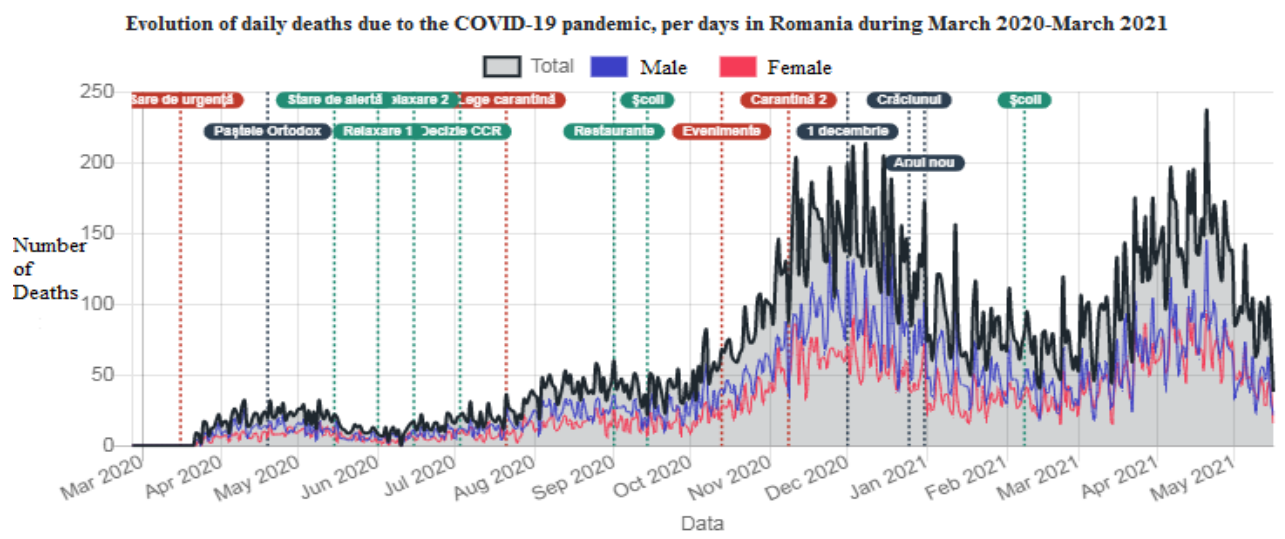

Figure no. 2. Evolution of daily deaths due to the COVID-19 pandemic, per days in Romania during March 2020-March 2021

Source: https://covid19.geo-spatial.org/statistici/decese 
In the last month Romania experienced the third wave of the pandemic. Several cities are facing an exponential increase in confirmed cases and hospitals have reached their maximum capacity in terms of ER seats. Paradoxically, this increase seems to be against the increase in the vaccination rate of the Romanian population and the tightening of the restrictions on the free movement of the population.

Economic impact

The restrictive measures taken by Romania to limit the spread of the disease have led to a significant reduction in demand (consumption and investment) and supply (production of goods and services). This reduction was achieved in two stages. In the first stage, there was a significant decrease in supply as a result of the crisis triggered by the COVID-19 pandemic, a decrease due to the measures implemented in order to reduce the spread of the virus. Thus appears the second stage where the effect of reducing demand is manifested as a consequence of reducing the income of the population. The reduction of incomes was felt especially by those who lost their jobs or their incomes decreased as a result of the closure of companies or the reduction of activity (Vasile, et al., 2020). The National Institute of Statistics conducted a statistical survey among managers of enterprises in manufacturing, construction, retail and services on their perception of the outlook for business activity in MarchApril 2020. According to this research, a reduction in turnover was estimated by $32 \%$ in March 2020 and by $40 \%$ in April 2020 compared to the same months in 2019. In conclusion, economic activities were affected in several fields of activity such as: transport, retail, construction, tourism, industry, culture, also according to the KPMG study conducted in the first four months of 2020. Consumers stay and work from home more, prioritize savings and do business in a digital environment more and more. Therefore, for companies according to the KPMG study, it is more important than ever to perceive what motivates customers, to analyze their strategy and business model to determine how they can adapt to keep pace with the changing needs of customers. The KPMG study identified, as of May 2020, four key trends affecting consumers and changing consumption habits. The four trends refer to: economic impact, erosion of trust, digital growth and the home as a new center of activity. Therefore, the use of digital alternatives is becoming a priority in the current context. In 2018, a study by the consulting firm McKinsey noted that the states of Central and Eastern Europe (CEE) have the necessary foundations for digitalization, with good primary and secondary education systems, a high number of graduates in the fields of science, technology, engineering, mathematics and ICT (Novak, et al., 2018). Also according to (Pastiu, et al., 2020) the latest trends in e-commerce, explicitly show substantial changes in online consumer behavior. In Romania, during the COVID-19 pandemic, the opportunity for the economy to be launched faster by increasing the degree of digitalization is achieved at a much slower rate and with much higher costs compared to other European countries. (Cioaca et al., 2020) In Romania, investments in the ICT field were not high due to the low percentage allocated from GDP to this field of activity and its development occurred in the same time with the consumer concerns of energy savings, keeping the trend of a low energy consumption in the digital area (Pelau and Acatrinei, 2019).

The social impact

Achieving a compliant economic balance is the main long range objective of a country, contributing to reducing uncertainty, creating an attractive business environment, attracting foreign direct investment and contributing to economic growth (Haller at al, 2018). This increases the confort and standards of living, reduces inequalities and creating the conditions for an economic justice to develop (Moise-Titei, 2015). The Romanian social protection measures, of the social categories affected by the external shock COVID 19, were in line with the practices of the European Union. (Beland, et al, 2020) In fact, there has been a forced digitization of certain activities, with effects on the diminishing the employment. In the same context, other researchers argue that in the new era of an developing European information society, scientific progress can be seen in all activities (Ghita, et al, 2020). This had a positive impact on the development of human society, as well as on the sustainable development of business in all sectors of activity by developing new skills and performance of employees (Busu and Gyorgy, 2016). Therefore, the Internet is becoming more and more important nowadays, even since starting before the pandemics, for the society and the economy (Pelau and Bena, 2010). Protecting consumer security must be done in accordance with all legal requirements and beyond so that users can fully benefit from the advantages of the modern interconnected and information-driven society (Dinu, 2011). 
According to the study prepared by Deloitte Global Marketing Trends in 2021, an important part of consumers consider that the new digital experiences are a satisfactory substitute for the activities they carried out before the COVID-19 pandemic. The Deloitte Global Marketing Trends 2021 study highlights the openness of consumers to brands that focus on achieving their own goal during a crisis period.

\section{Research methodology}

The study conducted in the health field is a research based on secondary data provided by WHO (Romania: Coronavirus Pandemic Country Profile). As one of the major changes in consumer behavior in 2020 as a result of the pandemics has reached health care services, the study is analyzing the evolution and the correlations between the macroeconomic indicators characterizing the COVID19 pandemic. ( $\mathrm{PwC}, 2020)$ The main research method used is the multiple linear modelling of total total cases depending upon the total number of deaths, new daily deaths and cases, reproductive rate and estimated new cases, smoothed. The secondary data used in the study for the application of the stated methods took into account the period 22.03.0202-22.03.2021 and were used to estimate the relationship between the total number of COVID-19 cases and its determinants, with the help of specialised softwares (EViews, Excel). Therefore, the following initially developed hypotheses were considered:

H1: Total number of deaths due to COVID-19 pandemic is significantly positively impacting the total number of COVID-19 cases given by days

H2: Increase in new COVID-19 cases negatively affects the total number of COVID-19 cases by days

H3: The growth new smoothed cases have a positive influence on the daily total number of total cases COVID-19

In conclusion, it was used the single-factorial and multifactorial regression method which implies an estimation of the regression function parameters through the OLS method.

\section{Results and discussions}

Before moving on to the analysis of the influences that the selected independent variables (new cases, total number of deaths, new_cases_smoothed and number of new deaths) have on the dependent variable, respectively the total number of cases COVID-19, the main descriptive characteristics of the independent variables were analyzed in the case of the study, including the transmission rate (Table no 1).

Table no 1. Descriptive statistics for the independent variables

\begin{tabular}{|c|c|c|c|c|c|}
\hline & $\begin{array}{l}\text { REPRODUCTIVE_ } \\
\text {-RATE }\end{array}$ & $\begin{array}{l}\text { TOTAL } \\
\text { DEATHS }\end{array}$ & $\begin{array}{l}\text { NEW } \\
\text { DEATHS }\end{array}$ & $\begin{array}{l}\mathrm{NEW}_{-} \\
\text {CASES_} \\
\text { SMOOTHED }\end{array}$ & $\begin{array}{l}\mathrm{NEW}_{-} \\
\mathrm{CASES}\end{array}$ \\
\hline Mean & 1.10 & 7628.09 & 60.84 & 2420.30 & 2640.35 \\
\hline Maximum & 2.18 & 22268 & 213 & 8521.28 & 10269 \\
\hline Minimum & 0.82 & 3 & 3 & 43.14 & 66 \\
\hline Std. Dev. & 0.22 & 7202.43 & 48.47 & 2340.13 & 2485.89 \\
\hline Mode & 1 & $\begin{array}{l}\text { Does not } \\
\text { exist }\end{array}$ & 22 & 324 & 320 \\
\hline $\begin{array}{l}\text { Coefficient of } \\
\text { homogeneity- } \%\end{array}$ & 20 & & & & \\
\hline
\end{tabular}

The average daily number of total deaths due to SARS COV2 was 7628.09 cases/day, not representative for the dataset due to the homogeneity coefficient which has a value of over $94 \%$. Regarding the average reproduction rate of COVID-19, the most common value of the transmission rate of the COVID-19 pandemic was the value 1, which means that mostly, an infected person 
transmitted the virus to a single person, on average. The average reproduction rate of COVID-19 was $1.10 /$ day, highly representative because the coefficient of variation of $20 \%$. The daily new deaths average was around 61 cases/day, not representative for the dataset with an homogeneity coefficient of $79.66 \%$. The average daily new cases value is 2641 new cases /day with a very low level of representativeness. Mostly, there were registered 320 new cases/day, over the last year. Regarding the new_cases_smoothed indicator, the most common value is 324 cases/day. This very high variation registered by some independent variables is due to the fact that this COVID-19 pandemic has a very dynamic unpreadictible evolution with a high rhythm of change. According to the linear multiple econometric models further developed, see Table 2, 99.57\% of the dependent variable TOTAL_CASES COVID-19 variation is explained by the regressors, holding constant the other factors of influence. There is a positive relationship between TOTAL_CASES COVID-19 daily and the independent variables NEW_CASES, NEW_CASES_SMOOTHED. From the regression output in Table no 2, it can be stated that the correlation coefficient for TOTAL-DEATHS daily with the value 41.09 , is positive and statistically significant, showing that an increase with one death in the TOTAL_DEATHS will generate an increase of 41 cases per day in TOTAL_CASES. This is validating the first initial hypothesis.

Table no. 2. Multiple regression output between TOTAL_CASES COVID-19 as dependent variable and NEW_CASES, TOTAL_DEATHS, NEW_CASES_SMOOTHED,

Dependent Variable: TOTAL_CAS̄ES NEW_DEATHS as regressors

Method: Least Squares

Sample: 3/22/2020 3/22/2021

Included observations: 366

TOTAL_CASES $=\mathrm{C}(1)+\mathrm{C}(2) * \mathrm{NEW}$ _CASES+C(3)*NEW_CASES_SMOOTHE $\mathrm{D}+\overline{\mathrm{C}}(4) * \mathrm{NEW}$ _DEATHS $+\mathrm{C}(5) * \mathrm{TOTAL}$ _DEATHS

\begin{tabular}{crcrc}
\hline \hline & Coefficient & Std. Error & t-Statistic & Prob. \\
\hline \hline C(1) & -43219.25 & 1762.993 & -24.51470 & 0.0000 \\
$\mathrm{C}(2)$ & -4.660849 & 1.266799 & -3.679234 & 0.0003 \\
$\mathrm{C}(3)$ & 4.858041 & 1.475011 & 3.293561 & 0.0011 \\
$\mathrm{C}(4)$ & 188.0708 & 56.21540 & 3.345540 & 0.0009 \\
$\mathrm{C}(5)$ & 41.09173 & 0.188300 & 218.2246 & 0.0000 \\
\hline \hline R-squared & 0.995623 & Mean dependent var & 281965.3 \\
Adjusted R-squared & 0.995574 & S.D. dependent var & 302764.3 \\
F-statistic & 20527.48 & Durbin-Watson stat & 0.068010 \\
\hline \hline
\end{tabular}

Source: own calculation, EViews estimation

The Romanian economy is obviously imbalance, because the number of deaths due to the COVID-19 pandemic is constantly increasing (Vasile at al, 2020) leading to a decrease in the workforce both in private and the state one and because of the restrictive measures preventing the human contacts. Another argument for the existence of an economic imbalance is the fact that many private sector companies are facing insolvency (especially SMEs), some even going bankrupt (especially that in tourism and public catering). The negative relationship between NEW_CASES and TOTAL_CASES (the increase with one new case / day will generate a decrease of approximately 5 cases in TOTAL_CASES), is validating the second initial hypothesis. In other words, the increase of COVID19 cases by multiplying the total number of cases leads to the collapse of the Romanian health system if the intensity of the infectious will stay high. In parallel with this negative effect, there will be a decrease in real GDP, i.e. business that generates investment and working places. On the other hand, the coefficients of the independent variables NEW_DEATHS and NEW_CASES_SMOOTHED have positive and statistically significant values (188.07 and 4.85, respectively) for a significance of $5 \%$. Thus, the appearance of a new case with a mild form of virus manifestation generates an increase of approximately 5 cases/day in total, an aspect that validates the third initial hypothesis. Since 
Significance $\mathrm{F}$ probability than the chosen significance level of $5 \%$, the model is well specified and valid for the datasets. So the model is depicting a real correlation between the dependent variable, Romanian daily TOTAL_CASES and the selected independent variables, according to the equation:

ESTIMATED TOTAL_CASES $=-43219.25-4.6608 * \mathrm{NEW}$ CASES $+4.8580 *$ NEW_CASES_SMOOTHED $+41.0917 *$ TOTAL_DEATH $+188.0708 * \bar{N} E W$ DEATHS

Being valid, the econometric model can be used to estimate future values of the dependent variable, disregarding other variables that might impact the total number of cases and have not been published or for which there are no continuous data series. The model is affected by multicollinearity between independent variables (Table no 3).

Table no. 3. Matrix of Correlations

\begin{tabular}{|c|c|c|c|c|c|}
\hline & $\begin{array}{l}\text { NEW- } \\
\text { CASES }\end{array}$ & $\begin{array}{l}\text { NEW_CASES_ } \\
\text { SMOOTHED }\end{array}$ & $\begin{array}{l}\text { TOTAL_D } \\
\text { EATHS }\end{array}$ & $\begin{array}{l}\text { NEW_DEATH } \\
\mathrm{S}\end{array}$ & $\begin{array}{r}\text { TOTAL } \\
\text { CASES }\end{array}$ \\
\hline NEW_CASES & 1.0000 & & & & \\
\hline $\begin{array}{l}\text { NEW_CASES_- } \\
\text { SMOOTHED } \\
\text { TOTAL DEAT }\end{array}$ & 0.9372 & 1. 000 & & & \\
\hline HS & 0.5496 & 0.5927 & 1.0000 & & \\
\hline NEW_DEATHS & 0.8909 & 0.9095 & 0.6214 & 1.0000 & \multirow[b]{2}{*}{1.0000} \\
\hline TOTAL_CASES & 0.5610 & 0.6084 & 0.9975 & 0.6376 & \\
\hline
\end{tabular}

It is found that between TOTAL_CASES and NEW_CASES there is a positive relationship of medium intensity (0.56) as well as between TOTAL_DEATHS and NEW_CASES_SMOOTHED (0.59). These correlations are explained by the evolution of the COVID-19 pandemic in the analyzed period.

\section{Conclusions and future research}

The economic and labor market recovery prospects are different from country to country, depending on several factors, as the degree of spread of the virus, the strictness and compliance of public health measures adopted to keep it under control, the sectorial composition of economies and the strength of national policy responses. The study based on secondary data showed that the health status in Romania depends significantly on the degree of infection of the population and the ability of the population to comply with the restrictions imposed by the competent government institutions. The study also highlighted that the variables that characterize and measure the degree of infection of the Romanian population are correlated, with direct effects on the standard of living, of pollution, changes in economic growth and the behavior of consumption. Due to the negative effects of the COVID-19 pandemic worldwide, the changes in consumer behavior will be occurring on long range if the restrictions will continue in all countries as well as the evolution of the COVID-19 pandemic goes on.

\section{Referencies}

Albu, L.L., et al, 2020. Evaluari ale impactului macroeconomic al COVID-19. Bucuresti: Academia Romana.

Beland, L, Ph., Brodeur, A., Wright, T., 2020. The Short-Term Economic Consequences of COVID19: Exposure to Disease, Remote Work and Government Response. IZA Disscution Paper, no. 13159.

Busu, M., Gyorgy, A., 2016. Real convergence, steps from adherence to integration. Amfiteatru Economic 18(42), pp.303-316. 
Cioaca, S.I., Cristache, S.E., Vuta, M., Marin, E., Vuta, M., 2020. Assessing the Impact of ICT Sector on Sustainable Development in the European Union: An Empirical Analysis Using Panel Data. Sustainability, 12(2), 592, pp.13-14.

Dinu, V., 2011. Responsabilitatea socială corporativă - Oportunitate de reconciliere a intereselor economice cu cele sociale şi de mediu. Amfiteatru Economic, XIII(29), pp.6-7.

Die Welt, 2020. Suntem amenintati de un nou virus usigas? Across the Globe, [online] Available at: $<$ https:/www.dw.com/ro/suntem-amenin\%C5\%A3a\%C5\%A3i-de-un-nou-virusuciga\%C5\%9F/a51917224> [Accessed 10 March 2021].

Deloitte, 2020. Global Marketing Trends in 2021 (report breaks down key insights for global CMOs. We've summarized six key takeaways that marketers can look into). [online] Available at: $<$ https://www.contentgrip.com/deloitte-global-marketing-trends-report/ Deloitte> [Accessed 12 March 2021].

Ernst/Young Rom, 2020. Cum a modelat COVID-19 comportamentul consumatorilor romani? [online] Available at: <https://www.ey.com/ro_ro/covid-19/comportamentul-consumatoruluiroman-in-contextul-covid-19> [Accessed 12 March 2021].

Ghita, S.I., Saseanu, A.S., Gogonea, R.M., Huidumac-Petrescu, C.E., 2018. Perspectives of Ecological Footprint in European Context under the Impact of Information Society and Sustainable Development. Sustainability, 10, Article number: 3224.

Haller, A.P., Butnaru, R.C., Butnaru, G.I., 2018. International Migrant Remittances in the Context of Economic and Social Sustainable Development. A Comparative Study of Romania-Bulgaria. Sustainability, 10(4), Article number: 1156.

KPMG, 2020. COVID-19 transformă comportamentul consumatorilor în intreaga lume, iar companiile trebuie să se adapteze rapid, [online] Available at: $<$ https:/home.kpmg/ro/ro/home/presa/comunicate-presa/2020/12/covid-19-schimbacomportamentul-consumatorilor-companiile-adaptare.html> [Accessed 12 March 2021].

Moise-Ţiței, A., 2015. An Empirical Measure for Economic Justice. Ovidius University Annals, Economic Sciences Series, 15(1), pp.314-317.

National Institute of Statistics, 2020. Evaluarea impactului COVID - 19 asupra mediului economic în lunile martie și aprilie 2020. Comunicat de presă Nr. 104/ 15 aprilie 2020 [online] Available at: $<$ www.insse.ro $>$ [Accessed 12 March 2021].

Novak, J., Purta, M., Marciniak, T., Ignatowicz, K., Rozenbaum, K., Yearwood, K., 2018. The rise of Digital Challengers. How digitization can become the next growth engine for Central and Eastern Europe, [online] McKinsey \& Company Across the Globe. Available at: $<$ https:/www.mckinsey.com/ /media/McKinsey/Featured\%20Insights/Europe/Central\%20and\%2 0Eastern\%20Europe\%20needs\%20a\%20new\%20engine\%20for\%20growth/The-rise-of-DigitalChallengers.ashx $>$ [Accessed 12 March 2021].

Pastiu, C.A., Oncioiu, I., Gardan, D.A., Maican, S.S., Gardan, I.P., Muntean, A.C., 2020. The Perspective of E-Business Sustainability and Website Accessibility of Online Stores. Sustainability, 12(22), Article number: 9780.

Pelau, C., Acatrinei, C., 2019. The Paradox of Energy Consumption Decrease in the Transition Period towards a Digital Society. Energies, 12(8), Article number: 1428.

Pelau, C., Bena, I., 2010. Percepttia riscului pe diferite segmente de consumatori în cadrul tranzactiilor de comert electronic si implicatiile asupra strategiei de marketing. Amfiteatru Economic, 12(28), pp.372-386.

Pelau, C., Sarbu, R., Serban, D., 2020. Cultural Influences on Fruit and Vegetable Food-Wasting Behavior in the European Union. Sustainability, 12, Article number: 9685.

PwC, 2020. Sondajul PWC din anul 2020 privind comportamentul de consum post COVID-19, "Global Consumer Insights Survey" 2020. [online] Available at: $<$ https://www.pwc.ro/ro/media/press-release-2020/sondaj-pwc-privind-comportamentul-deconsum-post-covid-19--cumpr.html> [Accessed 12 March 2021]. 
Statistici-Coronavirus COVID-19 România Project, 2020. Statistici-Coronavirus COVID-19 România. [online] Available at: <https://covid19.geo-spatial.org/statistici/decese> [Accessed 12 March 2021].

Savoiu, G., 2020. Cât de afectate de erori sunt statisticile şi modelările evoluţiei impactului virusului Covid-19? Revista Română de Statistică - Supliment nr. 5 / 2020, [online] Available at: $<$ https://www.upit.ro/ro/upit-pentru-comunitate/statistica-si-modelare> [Accessed 12 March 2021].

Valentina, V., Boboc, C., Ghiță, S., Apostu, S., Pavelescu, F.M., Mazilescu, R., 2020. Efectele pandemiei SARS COV 2 asupra ocuparii. Rolul politicilor publice si rezilienta pietei muncii in contextul adaptarii mediului de afaceri. Bucuresti: Academia Romana.

WHO, 2020. Situation Report 50, [online] Available at: <https://www.who.int/docs/defaultsource/coronaviruse/situation-reports/20200310-sitrep-50-covid-19.pdf?sfvrsn=55e904fb_2> [Accessed 12 March 2021].

WHO, 2020. Situation Report 51, 2020. Coronavirus disease 2019 (COVID-19): Situation Report - 51, [online] Available at: $<$ https://reliefweb.int/report/china/coronavirus-disease-2019covid-19-situation-report-51-11-march-2020> [Accessed 12 March 2021]. 